\title{
Impact of Pratylenchus penetrans on Establishment of Red Raspberry
}

Inga A. Zasada and Jerry E. Weiland, United States Department of Agriculture-Agricultural Research Service Horticultural Crops Research Laboratory, Corvallis, OR 97330; Z. Han and T. W. Walters, Washington State University (WSU) Northwestern Washington Research and Extension Center, Mt. Vernon, WA 98273; and P. Moore, WSU-Puyallup, Puyallup 98371

\begin{abstract}
Zasada, I. A., Weiland, J. E., Han, Z., Walters, T. W., and Moore, P. 2015. Impact of Pratylenchus penetrans on establishment of red raspberry. Plant Dis. 99:939-946.

The plant-parasitic nematode, Pratylenchus penetrans, is a major constraint to red raspberry (Rubus idaeus) production. To determine the impact of $P$. penetrans on the establishment and productivity of eight raspberry cultivars, $R$. niveus, and $R$. leucodermis, plants were grown in fumigated and nonfumigated soil. Then, soil and root populations of $P$. penetrans and plant productivity (vigor, cane height, biomass, and yield) were monitored over 2 years. In a separate experiment, the role that soil type plays in mediating $P$. penetrans populations and raspberry establishment was investigated. At 6 and 12 months after planting, population densities of $P$. penetrans were lower in fumigated than in nonfumigated soil; this trend continued 18 months after planting. All cultivars and $R$. leucodermis were found to be extremely susceptible to damage caused by $P$. penetrans. By the end of the experiment, yield was the

most sensitive indicator of plant productivity among cultivars, with losses in nonfumigated soil ranging from 63 to $100 \%$ of those observed in fumigated soil. However, there was no difference in the productivity of $R$. niveus plants grown in nonfumigated versus fumigated soils. Results also indicated that the damage potential of $P$. penetrans was greater on sandy loam versus silt loam soils. The total plant biomass of 'Meeker' raspberry was $46 \%$ lower in a sandy loam soil containing $P$. penetrans compared with soil without $P$. penetrans; this trend was not observed consistently in a silt loam soil. Despite the fact that soil fumigation is increasingly more limited by regulations, this study shows the utility of fumigation in reducing $P$. penetrans populations for a sufficient period of time to ensure that newly planted raspberry seedlings can become successfully established.
\end{abstract}

The Pacific Northwest region of the United States comprises 92\% of the processed red raspberry (Rubus idaeus L.) acreage nationwide. In northwestern Washington, the raspberry industry generates $\$ 57$ million in revenue annually and encompasses 4,006 ha of production (30). Pratylenchus penetrans (Cobb, 1917) Filipjev and Schuurmans, the root lesion nematode, is an economically important pathogen of raspberry and is widespread in the Pacific Northwest region of North America. A survey in the Fraser Valley of British Columbia identified 16 genera of plant-parasitic nematodes associated with raspberry; $P$. penetrans was the most commonly encountered, occurring in $90 \%$ of the samples (18). More recently, a survey conducted in two northwestern Washington counties, Skagit and Whatcom, detected $P$. penetrans in $100 \%$ of the samples, with population densities of $P$. penetrans nematodes averaging 1,450/g of dry root and 37 per $100 \mathrm{~g}$ of dry soil (12).

$P$. penetrans is a migratory endoparasite with over 400 host plant species, including commercial crops, cover crops, and weeds (7). This nematode can complete several generations in a single growing season, depending upon soil temperature. All stages of the nematode move between soil and roots and feed and migrate in root cortical tissue. Damage caused by $P$. penetrans generally includes a reduction in fine root abundance and the wounding of root tissue, which appears as necrotic lesions on the roots (19). When individual and

Corresponding author: I. A. Zasada; E-mail: inga.zasada@ ars.usda.gov

Current address: Z. Han: Department of Crop Sciences, University of Illinois, Urbana 61801.

Current address: T. W. Walters: Walters Ag. Research, Anacortes, WA 98221.

Mention of trade names or commercial products in this article is solely for the purpose of providing scientific information and does not imply recommendation or endorsement by the United States Department of Agriculture.

Accepted for publication 24 November 2014

http://dx.doi.org/10.1094/PDIS-09-14-0980-RE

This article is in the public domain and not copyrightable. It may be freely reprinted with customary crediting of the source. The American Phytopathological Society, 2015. combined effects of $P$. penetrans and Xiphinema bakeri on 'Willamette' raspberry were evaluated, $P$. penetrans alone had the greatest effect on plant establishment, resulting in $24 \%$ plant mortality (17). In the same study, $P$. penetrans reduced the weight of first year growth by $66 \%$. In a field infested with $P$. penetrans, X. rivesi, and Meloidogyne hapla, preplant soil fumigation with 1,3-dichloropropene increased yields of 'Boyne' raspberry by 98,59 , and $18 \%$ in the first, second, and third year of production, respectively, compared with yield in nontreated areas (2). P. penetrans was the most abundant plant-parasitic nematode in that study and it was assumed to be responsible for most of the growth reduction.

Since the 1940s, growers have been able to manage plant-parasitic nematodes in raspberry by preplant soil fumigation or postplant treatment of soil with fenamiphos. In recent years, many effective chemical management tools have been removed from the market, with fenamiphos having been cancelled in the United States (31) and methyl bromide phased out for all U.S. commodities. In addition, broadcast fumigation will become more burdensome with new EPA reregistration eligibility decisions (32); raspberry growers currently rely upon a combination of 1,3-dichloropropene and chloropicrin (Telone products) for preplant fumigation. As a result, the raspberry industry is at a juncture where new, long-term, and economically viable strategies for plant-parasitic nematode management must be developed.

Previous research on the impact of $P$. penetrans on raspberry establishment and productivity was primarily conducted on the outdated raspberry Willamette. The study by McElroy (17) mentioned previously, reported yield and growth losses by plant-parasitic nematodes on Willamette. In addition, research conducted in Canada on the population dynamics and distribution of $P$. penetrans in raspberry was also carried out in fields planted with Willamette $(11,33)$. Currently, there is no information about the response of raspberry cultivars that are now widely planted in the Pacific Northwest to $P$. penetrans (35).

Soil type, especially soil texture, appears to be one of the most important factors that affects the damage potential of $P$. penetrans in a region but information on how soil type influences the damage potential of this nematode in raspberry establishment is relatively meager. Soil texture influences the damage potential of $P$. penetrans 
through a combination of factors that include the efficiency of movement and penetration of roots, survival, and fecundity. In general, $P$. penetrans causes more severe damage in sandy soils than in finertextured soils $(9,25,28)$. A sandy loam soil has previously been reported to be the most suitable soil type for maximizing the movement of $P$. penetrans and several other species of Pratylenchus (29). However, within the genus Pratylenchus, population abundance in soil textures can vary. $P$. zeae was abundant in sandy soils, whereas $P$. hexincisus was abundant in finer-textured soils (21). Endo (9) also observed more rapid population growth of $P$. brachyurus in sandy loam soils compared with a sandy soil.

The overarching goal of this research program is to generate information to help direct raspberry growers in the management of $P$. penetrans. The goals of this research were to (i) evaluate the response of raspberry cultivars to $P$. penetrans parasitism; (ii) evaluate the field performance of $R$. leucodermis and $R$. niveus, two Rubus spp. identified as poor hosts of $P$. penetrans in greenhouse studies (39); and (iii) determine whether the damage potential of $P$. penetrans was similar in two different soil types common in northwest Washington.

\section{Materials and Methods}

Impact of $P$. penetrans on establishment of red raspberry cultivars $R$. niveus and $R$. leucodermis. A field trial was established in Burlington, WA in October 2010 on a Mt. Vernon very fine sandy loam (coarse-loamy, mixed, nonacid, mesic Aeric Fluvaquents). This field had previously been planted to raspberry and had a history of high population densities of $P$. penetrans. No other economically important plant-parasitic nematodes were found to be present at this site (19). The experiment was a split-plot design replicated six times, with main plot being fumigated or not and subplots being raspberry cultivars and Rubus spp. arranged according to a completely randomized design within the main plots. Beds ( $0.9 \mathrm{~m}$ wide by $0.2 \mathrm{~m}$ high) were formed with a Rain-flo model 2600 bed shaper (Rain-Flo Irrigation, East Earl, PA). Fumigated main plots were treated with Telone C-35 at $433 \mathrm{~kg} / \mathrm{ha}$ (65:35, 1,3-dichloropropene/chloropicrin; Dow Agrosciences, Indianapolis IN). All plots were covered with black Pliant Blockade virtually impermeable film (Pliant Plastics, Spring Lake, MI) immediately after bed formation and fumigation.

In April 2011, subplots (5 $\mathrm{m}$ long by $1.2 \mathrm{~m}$ wide) were established within fumigated and nonfumigated main plots. Each subplot was sampled to determine initial population densities of $P$. penetrans. From each subplot, eight soil cores $(2.5 \mathrm{~cm}$ in diameter by $25 \mathrm{~cm}$ deep) were collected at equal distances along the plot from the center of the plot and combined. Mixed stages of $P$. penetrans were extracted from a 50-g subsample of soil using the Baermann funnel method and nematodes were collected after 5 days (1). Nematodes were counted using a stereomicroscope at $\times 40$ magnification; $P$. penetrans population densities were expressed as number of nematodes per $100 \mathrm{~g}$ of dry soil. From these samples, 25 females were hand picked and identified morphologically as $P$. penetrans (lateral fields with four lines, labial region slightly offset from body, and tail generally rounded with a smooth tip) (5); in addition, males were numerous, a diagnostic trait for this species. The dry weights of 10 randomly selected samples of soil were determined by placing the soil samples in a $70^{\circ} \mathrm{C}$ oven for 1 week.

Tissue-culture raspberry plants, approximately $15 \mathrm{~cm}$ tall, in $400-\mathrm{cm}^{3}$ soilless media plugs were propagated at Washington State University (WSU)-Puyallup, Puyallup. Subplot treatments were the raspberry cultivars 'Anne', 'Caroline', and 'Heritage' (primocane fruiting cultivars that produce fruit on first-year growth), 'Cascade Bounty', 'Chemainus', 'Meeker', 'Saanich', and Willamette (floricane fruiting cultivars which produce fruit on second-year growth), plus $R$. leucodermis and $R$. niveus; subplots comprised five plants of each cultivar or species spaced $0.8 \mathrm{~m}$ apart. $R$. leucodermis and $R$. niveus were included in the trial because both were identified as poor hosts for $P$. penetrans in greenhouse evaluations (39). In nonfumigated main plots, an additional $70 \mathrm{~g}$ of soil from an adjacent row infested with $30( \pm 3) P$. penetrans per $100 \mathrm{~g}$ of soil was added around the root zone of each transplant to ensure the presence of P. penetrans.
Fertility, irrigation, and pest management practices followed recommended practices for the region (15). To further protect the plants in fumigated plots from $P$. penetrans, two nematicides were applied in the spring of 2012: fosthiazate (EC 900; Syngenta Crop Protection, Greensboro, NC) was applied at $919 \mathrm{ml} / \mathrm{ha}$ (fosthiazate at 5,044 g/ha) and oxamyl (Vydate; DuPont, Wilmington, DE) was applied at $1,532 \mathrm{ml} / \mathrm{ha}$ (oxamyl at $367 \mathrm{~g} / \mathrm{ha}$ ). The nematicides were applied together with a $\mathrm{CO}_{2}$-powered backpack sprayer in a volume of 1 liter/ subplot using a single-nozzle boom (8006 flat-fan nozzle; Teejet, Wheaton, IL) sprayed directly on the soil in a 1.2-m-wide band centered on the row. Rates for these applications were calculated as directed sprays of the full rate concentrated in the band (i.e., the rate applied was the actual amount used per hectare of crop but the product was concentrated in a 1.2-m-wide band) (34). Each application was followed by rainfall or overhead water application with a hose of at least $1 \mathrm{~cm}$. Nonfumigated plots received no nematicide and no additional overhead water application. In addition, this field had a known history of root rot caused by Phytophthora rubi (W. F. Wilcox \& J. M. Duncan) W. A. Man in 't Veld 2007; therefore, mefenoxam (Ridomil Gold; Syngenta) was applied to beds at $3.1 \mathrm{ml} / \mathrm{m}$ of row and aluminum Tris (Aliette WDG; Bayer CropScience, Kansas City, MO) was applied to foliage at $5.5 \mathrm{~kg} / \mathrm{ha}$ in April 2011 and 2012, respectively.

Plant performance was evaluated over the course of the experiment. In July 2011 and 2012, a vigor rating was assigned to each plant in each subplot using a 0 -to- 3 scale, where $0=$ dead, $1=$ very small, $2=$ larger than 1 but all or most of the canes below the top wire ( $150 \mathrm{~cm}$ above the soil surface), and $3=$ healthy. The average of these values for each subplot was calculated to determine overall plant vigor within plots. In August 2011, the height of the longest cane of each plant was determined, and values were averaged to determine subplot plant height. In 2012, berries in all subplots were harvested weekly from 5 through 30 July with a commercial mechanical harvester (Littau, Stayton, OR). At the end of the experiment (September 2012), the canes of the remaining three plants (after one plant/subplot was harvested destructively in both September 2011 and 2012; see below) in each subplot were mowed, air dried, and placed in a $70^{\circ} \mathrm{C}$ oven for 7 days, after which total aboveground biomass was determined.

To determine population dynamics of Pratylenchus penetrans in roots and soils of subplots, samples were collected in September 2011 and April and September 2012. Eight soil cores (2.5 cm in diameter by $25 \mathrm{~cm}$ deep) were collected at equal distances along the plot within $15 \mathrm{~cm}$ of the crown of a plant from each subplot, combined, and mixed, and $P$. penetrans was extracted as described previously. In addition, two $15-\mathrm{cm}^{3}$ root cores to a depth of $25 \mathrm{~cm}$ were collected within a $20-\mathrm{cm}$ radius of two different plant crowns using a square-blade shovel. $P$. penetrans were then extracted from fine roots $(\leq 2 \mathrm{~mm}$ in diameter) under intermittent mist for 1 week (1). Extracted roots were placed in a $70^{\circ} \mathrm{C}$ oven for 1 week before measuring dry weights. Nematodes were counted using a stereomicroscope at $\times 40$ magnification and expressed as number of $P$. penetrans nematodes per gram dry root.

In September 2011 and 2012, one plant was harvested destructively from each subplot to further evaluate the impact of $P$. penetrans on plant establishment. A $60-\mathrm{cm}^{2}$ area was delineated around the plant to be harvested and the edge of this area was carefully cut using a square-blade shovel down to a depth of approximately $30 \mathrm{~cm}$. Then, the plant was pried out of the ground while attempting to retain as many roots as possible before transportation to a washing area, where the roots were washed free of soil. Aboveground biomass was separated from the root system, air dried, then placed in a $70^{\circ} \mathrm{C}$ oven for 7 days, and dry weight was determined. A subsample of fine roots (roots $\leq 2 \mathrm{~mm}$ ) was collected for $P$. penetrans extraction, as described above. The remaining root material, as well as roots from which nematodes were extracted, were placed in a $70^{\circ} \mathrm{C}$ oven for 7 days before determining dry weights. $P$. penetrans populations were enumerated using a dissecting microscope at $\times 40$ magnification and were expressed as number of $P$. penetrans nematodes per gram of dry root and total $P$. penetrans in roots. 
Because the plots had been treated with fungicide to manage Phytophthora root rot, the decline observed in some plants of $R$. leucodermis and $R$. niveus could not be attributed to Phytophthora rubi. To further eliminate the contribution of production-limiting pathogens other than Pratylenchus penetrans, soil and plant samples were collected to determine the presence of Verticillium dahliae Kleb. 1913, a known pathogen of Rubus spp. (3). To assess the presence of $V$. dahliae in the soil, five soil cores $(2 \mathrm{~cm}$ in diameter by $25 \mathrm{~cm}$ deep) were collected adjacent to all plants remaining within each subplot in December 2011 (up to four samples/subplot). Soil samples within each subplot were combined and mixed thoroughly to generate a single composite soil sample. The presence and abundance of $V$. dahliae propagules in each composite sample were assayed by using a modified Andersen sampler technique (4). Briefly, soil was air dried for 2 weeks at room temperature, sieved through a $1-\mathrm{mm}$-diameter sieve, and then dispersed as $0.05-\mathrm{g}$ subsamples onto 20 petri plates containing $20 \mathrm{ml}$ of NP10 medium (27), a semiselective medium for $V$. dahliae. Plates were incubated for 2 weeks in the dark at $20^{\circ} \mathrm{C}$, washed under running water to remove soil, then assessed for the number of $V$. dahliae colonies with diagnostic microsclerotia (13). To assess whether plants were infected by $V$. dahliae, a single stem was cut from the remaining plants in each subplot in July 2012 (up to four plants/subplot). Stems were cut at the soil line, trimmed to $30 \mathrm{~cm}$ long, placed into a plastic bag, then stored at $4^{\circ} \mathrm{C}$ until the stems were assessed for infection within 2 weeks. Stems were surface disinfested by immersion in $95 \%$ ethanol, then briefly flamed. The basal $3 \mathrm{~cm}$ of each stem was then sectioned into 1-mm-thick transverse sections and plated onto $20 \mathrm{ml}$ of NP10. Plates were incubated as described above and assessed for the presence of $V$. dahliae colonies with diagnostic microsclerotia.

Ratings for plant vigor in 2011 and 2012 were analyzed for the main effects of fumigation, genotype, block, and fumigation-genotype interaction using a method for nonparametric analysis of ordinal data based on ranks (26). Plant height data were analyzed for effects of fumigation, genotype, fumigation-genotype interaction, and block using a mixed linear model analysis of variance (ANOVA), with fumigation and genotype as fixed factors and block as a random factor. Plant biomass and yield data in 2012 were analyzed using the same model as for plant height data after transforming both dependent variables with the square root to control for heteroscedasticity. Soil and plant population data for $P$. penetrans were initially transformed by $\ln (x+1)$ to correct for heteroscedasticity and then analyzed for effects of fumigation, genotype, fumigation-genotype interaction, and block using a mixed linear model ANOVA, with fumigation and genotype as fixed factors and block as a random factor. Fumigation-genotype interactions were not evident in any of the analyses performed $(P \geq 0.082$ or effect size $<7 \%$ of total model variability). Therefore, data for fumigated and nonfumigated treatments were analyzed together, not separately. Cultivar treatment means within and across fumigated and nonfumigated treatments for each response variable (e.g., plant vigor, nematode population data, and so on) were separated using Tukey's test $(P=0.05)$ with pairwise comparisons for specific contrasts. All analyses were performed using Minitab Statistical Software release 16 (Minitab Inc., State College, PA).

Influence of soil type on damage potential of $P$. penetrans to red raspberry. Two farms (both in Whatcom County, WA) with relatively high population densities of $P$. penetrans ( $>100$ P. penetrans nematodes per $100 \mathrm{~g}$ of dry soil) were chosen to represent two local soil types. The identity of $P$. penetrans at both farms was determined as described above. At each farm, soil was collected at two different times to establish independent, repeated microplot trials. At each farm, soil was collected from infested raspberry beds, placed in covered, 68-liter plastic bins, and stored at room temperature for a month before being used to establish microplot trials. The two soils used in these experiments were (i) Lynden sandy loam, 56\% sand, 32\% silt, $11 \%$ clay, $\mathrm{pH} 6.1$, and organic matter $5.1 \%$, and (ii) Kickerville silt loam, $46 \%$ sand, $40 \%$ silt, $13 \%$ clay, $\mathrm{pH} 6.3$, and organic matter $7.8 \%$. A portion of each soil was shredded using a soil shredder (Model 10; Royer, Oshkosh, WI), and part of this soil was treated with a combination of the nematicides oxamyl (oxamyl at $367 \mathrm{~g} / \mathrm{ha}$ and Vydate $\mathrm{L}$ at $0.22 \mathrm{ml} / \mathrm{liter}$ of soil) and fosthiazate (fosthiazate at $5,044 \mathrm{~g} / \mathrm{ha}$ and fosthiazate EC900 at $0.13 \mathrm{ml} /$ liter of soil) to eliminate $P$. penetrans. Oxamyl and fosthiazate were applied together using a $\mathrm{CO}_{2}$-powered backpack sprayer with a single-nozzle boom in a volume of 1 liter of water per 15 liters of soil. Treated soil was mixed well and covered with a plastic tarp for 3 days. After treatment, the $P$. penetrans population density was determined by extracting nematodes from a subsample of $100 \mathrm{~g}$ of soil using the Baermann funnel method. Soil treated with nematicides was designated as the nematicide treatment (targeted population of $0 P$. penetrans nematodes per $100 \mathrm{~g}$ of dry soil). To create infested treatments, treated soil from each location was then mixed with nontreated soil to achieve a low population (targeted population of $75 P$. penetrans nematodes per $100 \mathrm{~g}$ of dry soil) and a high population (targeted population of 160 P. penetrans nematodes per $100 \mathrm{~g}$ of dry soil) (18). No other economically important plant-parasitic nematodes were found in these soil samples (19). The remaining soil from each site was pasteurized to obtain a targeted population of $0 P$. penetrans nematodes per $100 \mathrm{~g}$ of dry soil. To achieve optimum pasteurization, each soil was passed through a sieve (1-cm-diameter mesh) to remove rocks and plant debris. The soil was then heated to $60^{\circ} \mathrm{C}$ with steam, maintained at this temperature for $1 \mathrm{~h}$, and then shredded. Soil subjected to each of the four treatments (pasteurized, nematicide, and low and high initial nematode populations) was mixed for 3 min using a commercial concrete mixer (255-liter drum capacity, Model MC94SH8; Multiquip, Carson, CA). The drum of the mixer was washed and sanitized using $70 \%$ isopropyl alcohol after mixing each soil treatment. Soils for all treatments were stored in a covered area after mixing.

Before establishing microplots in a field, five beds (each $23 \mathrm{~m}$ long, $0.45 \mathrm{~m}$ wide, and $0.45 \mathrm{~m}$ tall) were created using a bed shaper (Model 2600) at the WSU Mount Vernon Northwestern Washington Research and Extension Center, Mount Vernon. Holes (0.4 $\mathrm{m}$ in diameter by $0.4 \mathrm{~m}$ deep) were augured every $0.9 \mathrm{~m}$ along the rows using an auger mounted on a tractor. Buckets, each 19 liters in capacity (27 $\mathrm{cm}$ in upper diameter, $24 \mathrm{~cm}$ in lower diameter, and $35 \mathrm{~cm}$ in height) were used as microplots. Four holes, each $1 \mathrm{~cm}$ in diameter, were drilled in the bottom of each bucket to facilitate drainage. The experiment was arranged in a randomized complete block design as a factorial with two soil types and four soil treatments (pasteurized, nematicide, and low and high initial nematode populations). Each treatment combination was replicated five times and the experiment was conducted twice. Approximately 18 liters of the appropriate soil treatment was loaded into each bucket. Two soil cores $(2.5 \mathrm{~cm}$ in diameter by $25 \mathrm{~cm}$ deep) were then collected from each bucket and $P$. penetrans was extracted from $50 \mathrm{~g}$ using the Baermann funnel method. This sample represented the initial soil population density of $P$. penetrans and is expressed as number of $P$. penetrans nematodes per $100 \mathrm{~g}$ of dry soil.

Rooted canes of Meeker raspberry were graded from largest to smallest and then arranged so that each replication was planted with canes of similar size. One cane was planted in each bucket. The buckets of soil were then moved outside and a preemergent application of the herbicide oryzalin (Surflan; United Phosphorus, Inc., King of Prussia, PA) was applied to the soil in each bucket at the rate of 11.2 liter/ha, followed by irrigation with $1.3 \mathrm{~cm}$ of water. After 5 days, the buckets were moved to the field and placed in the holes. Each bucket was covered to the rim with soil from the field. Drip irrigation lines were placed in each bucket. Irrigation and nutritional needs followed recommended practices for the region (15). Fertilizer (N-P-K, 25-14-0) was applied at a rate of $20 \mathrm{~g} / \mathrm{pot}$ in April 2012. In August 2012, the fungicides pyraclostrobin + boscalid (Pristine; BASF Corporation, Florham Park, NJ) were applied to leaves at $1.4 \mathrm{~kg} / \mathrm{ha}$ to control cane and leaf rust (Kuehneola uredines (Link) Arthur 1906).

In August 2012, the number and height of all primocanes were assessed in each microplot. In September 2012, the experiments were terminated. Plants were removed from each microplot and moved to 68-liter plastic bins in which the roots were shaken free of soil. The primocanes were cut from the roots and both were placed into a paper 
bag. Roots and shoots were dried at $70^{\circ} \mathrm{C}$ for 7 days before determining total plant dry weight. Fine roots (diameter $\leq 2 \mathrm{~mm}$ ) were collected along with soil from each plot and processed, and nematodes were enumerated as described above.

Plant growth and $P$. penetrans population densities were subjected to ANOVA using SAS (version 9.2; SAS Institute, Cary, NC), with soil type and treatment as fixed effects and trial and replication as random effects. In each trial, population densities of $P$. penetrans in the pasteurized treatment were consistently zero. Thus, to avoid extremely heterogeneous variances, population densities of $P$. penetrans in the pasteurized treatment were not included in the ANOVA. To fit the assumptions of homogeneity or normality, all population density data for $P$. penetrans were square root transformed for trial 1 . In trial 2, initial population density data for $P$. penetrans were arcsine transformed and final population density data for $P$. penetrans in roots were square root transformed. Results were analyzed separately for each trial because of a significant trial main effect and significant interactions of trial with other factors in the ANOVA. Data were analyzed using PROC MIXED; means separations were performed using the LSMEANS statement, which adjusts all pairwise differences by default in PROC MIXED, and the macro program "Pdmix800.sas" (23) was used to generate means separations.

\section{Results}

Impact of $P$. penetrans on establishment of red raspberry cultivars, $\boldsymbol{R}$. niveus, and $\boldsymbol{R}$. leucodermis. Initially, soil fumigation almost completely eliminated $P$. penetrans from the soil. Population densities in fumigated soil were almost undetectable in spring 2011 $(1 \pm 1$ nematodes per $100 \mathrm{~g}$ of soil) compared with those in nonfumigated soil (93 \pm 9 nematodes per $100 \mathrm{~g}$ of soil). At 6 (fall 2011) and 12 (spring 2012) months after planting, this difference between fumigation treatments continued, with consistently lower soil and root population densities of $P$. penetrans in fumigated soil than in nonfumigated soil (Table 1). At the end of the experiment, 18 months after planting (fall 2012), there were only four instances where soil or root population densities of $P$. penetrans were statistically similar in fumigated versus nonfumigated soil. However, the general tendency for population densities to be, on average, 20 times greater in nonfumigated soil than in fumigated soil still held. Among the raspberry cultivars and Rubus spp. grown in nonfumigated soil, there was no evidence to indicate that any particular cultivar or Rubus sp. consistently supported higher $P$. penetrans population densities than another (Table 1).

Four months after planting, Anne, Caroline, Meeker, Saanich, and Willamette raspberry grown in nonfumigated soil had significantly less $(26 \%)$ plant vigor than cultivars grown in fumigated soil
(Table 2). This trend continued into the next year, 16 months after planting, for the same cultivars. No difference in vigor was observed in either year for $R$. leucodermis or $R$. niveus grown in nonfumigated versus fumigated soils, or for the remaining red raspberry cultivars. When plant vigor was considered across cultivars and Rubus spp. grown in fumigated soil, Heritage was always the least vigorous cultivar included in the trial. For plant height, only Cascade Bounty and R. leucodermis were shorter in nonfumigated soil than in fumigated soil (Table 2). In fumigated soil, $R$. leucodermis produced the tallest plants while Heritage had the shortest plants; however, the height of Heritage was similar to that of Caroline, Cascade Bounty, and Chemainus. Of the two measures of plant performance considered in 2012, yield and total plant biomass, yield was the most sensitive indicator of differences among cultivars and Rubus spp. Yield was significantly less for most cultivars and Rubus spp. grown in nonfumigated soils than in fumigated soils, with losses of 63 to $100 \%$ (Table 2). The exception was the low-yielding Heritage, for which there was no difference in yield of plants grown in nonfumigated versus fumigated soils. A comparison of yield between $R$. niveus grown in nonfumigated versus fumigated soils was not possible because no fruit was produced by this species during the study. In fumigated soils, Meeker was the highest-yielding cultivar, with a yield similar to that of Willamette and Cascade Bounty. The lowest-yielding cultivar in fumigated soil was Heritage, which had a yield similar to that of Caroline and Chemainus. The final measurement of plant performance, aboveground biomass (collected at the termination of the experiment), indicated that all of the cultivars and $R$. leucodermis had less biomass in nonfumigated soils than in fumigated soils. Biomass losses were 64 to $92 \%$ (Table 2). The exception was $R$. niveus, with no difference in biomass in nonfumigated versus fumigated soils. In fumigated soil, $R$. niveus produced the greatest amount of biomass of any of the cultivars and Rubus spp.

Six months after planting, there were fewer $P$. penetrans nematodes per gram of root and total $P$. penetrans in roots of raspberry cultivars and Rubus spp. planted into fumigated versus nonfumigated soil (Table 3). These differences ranged from 7 to 1,500 times more $P$. penetrans nematodes per gram of root and 4 to 456 times more total nematodes in roots of nonfumigated versus fumigated plants. The following year, 18 months after planting, despite larger numerical differences in $P$. penetrans population densities in roots of plants grown in fumigated versus nonfumigated soil, there were few statistically supported differences (Table 3 ). The exceptions were fewer $P$. penetrans nematodes per gram of root in Cascade Bounty, Willamette, and both Rubus spp. grown in fumigated versus nonfumigated soils. Only $R$. niveus had fewer total $P$. penetrans nematodes in roots when grown in fumigated versus nonfumigated soil, with 400 times more

Table 1. Population densities of Pratylenchus penetrans in soil and in roots of red raspberry (Rubus idaeus) cultivars, R. leucodermis, and R. niveus grown in soil fumigated $(\mathrm{F})$ or not fumigated $(\mathrm{NF})^{\mathrm{z}}$

\begin{tabular}{|c|c|c|c|c|c|c|c|c|c|c|c|c|}
\hline \multirow[b]{4}{*}{ Cultivar or species } & \multicolumn{12}{|c|}{$P$. penetrans nematodes/g of } \\
\hline & \multicolumn{4}{|c|}{ Fall 2011} & \multicolumn{4}{|c|}{ Spring 2012} & \multicolumn{4}{|c|}{ Fall 2012} \\
\hline & \multicolumn{2}{|c|}{ Soil } & \multicolumn{2}{|c|}{ Root } & \multicolumn{2}{|c|}{ Soil } & \multicolumn{2}{|c|}{ Root } & \multicolumn{2}{|c|}{ Soil } & \multicolumn{2}{|c|}{ Root } \\
\hline & $\mathbf{F}$ & NF & $\mathbf{F}$ & NF & $\mathbf{F}$ & $\mathbf{N F}$ & $\mathbf{F}$ & NF & $\mathbf{F}$ & NF & $\mathbf{F}$ & NF \\
\hline Anne & $5 \mathrm{a}$ & $328 \mathrm{c}$ & $207 \mathrm{a}$ & $5,672 \mathrm{~b}$ & $5 \mathrm{a}$ & $411 \mathrm{c}$ & $11 \mathrm{a}$ & $1,631 \mathrm{~d}$ & $33 a b c$ & $924 \mathrm{de}$ & $206 \mathrm{a}$ & $6,589 \mathrm{c}$ \\
\hline Caroline & $1 \mathrm{a}$ & $92 \mathrm{bc}$ & $42 \mathrm{a}$ & $9,434 \mathrm{~b}$ & $3 \mathrm{a}$ & $267 \mathrm{c}$ & $21 \mathrm{ab}$ & $3,749 \mathrm{~d}$ & $18 \mathrm{ab}$ & $1,032 \mathrm{e}$ & $298 \mathrm{a}$ & $2,567 b c$ \\
\hline Cascade Bounty & $2 \mathrm{a}$ & $109 \mathrm{bc}$ & $3 \mathrm{a}$ & $9,595 \mathrm{~b}$ & $1 \mathrm{a}$ & $215 \mathrm{c}$ & $1 \mathrm{a}$ & $2,789 \mathrm{~d}$ & $12 \mathrm{ab}$ & $570 \mathrm{de}$ & $55 \mathrm{a}$ & $6,335 b c$ \\
\hline Chemainus & $0 \mathrm{a}$ & $137 \mathrm{bc}$ & $42 \mathrm{a}$ & $11,898 \mathrm{~b}$ & $42 \mathrm{ab}$ & $225 \mathrm{c}$ & $85 a b c$ & $1,332 \mathrm{~d}$ & 59 abcd & 464 cde & $152 \mathrm{a}$ & $7,305 \mathrm{c}$ \\
\hline Heritage & $0 \mathrm{a}$ & $142 \mathrm{bc}$ & $5 \mathrm{a}$ & $6,036 \mathrm{~b}$ & $1 \mathrm{a}$ & $143 \mathrm{c}$ & $1 \mathrm{a}$ & $750 \mathrm{~cd}$ & $24 a b$ & $451 \mathrm{de}$ & $394 a b$ & $4,239 \mathrm{bc}$ \\
\hline Meeker & $6 a$ & $103 \mathrm{bc}$ & $13 \mathrm{a}$ & $6,597 \mathrm{~b}$ & $15 \mathrm{a}$ & $270 \mathrm{c}$ & $24 \mathrm{a}$ & $588 \mathrm{~d}$ & $69 \mathrm{abc}$ & 495 cde & $352 \mathrm{a}$ & $2,306 \mathrm{bc}$ \\
\hline Saanich & $1 \mathrm{a}$ & $235 \mathrm{bc}$ & $1 \mathrm{a}$ & $7,677 \mathrm{~b}$ & $15 \mathrm{ab}$ & $174 \mathrm{c}$ & $92 \mathrm{a}$ & $744 \mathrm{~cd}$ & $22 \mathrm{ab}$ & $533 \mathrm{de}$ & $373 \mathrm{a}$ & $3,866 \mathrm{bc}$ \\
\hline Willamette & $2 \mathrm{a}$ & $225 \mathrm{c}$ & $13 \mathrm{a}$ & $6,238 \mathrm{~b}$ & $16 \mathrm{a}$ & $278 \mathrm{c}$ & $3 \mathrm{a}$ & $2,004 \mathrm{~d}$ & $11 \mathrm{ab}$ & 209 bcde & $43 \mathrm{a}$ & $1,695 \mathrm{bc}$ \\
\hline R. leucodermis & $0 \mathrm{a}$ & $41 \mathrm{~b}$ & $26 \mathrm{a}$ & $1,717 \mathrm{~b}$ & $1 \mathrm{a}$ & $72 \mathrm{bc}$ & $1 \mathrm{a}$ & $368 \mathrm{bcd}$ & $43 \mathrm{ab}$ & $618 \mathrm{de}$ & $57 \mathrm{a}$ & $1,808 \mathrm{bc}$ \\
\hline$R$. niveus & $2 \mathrm{a}$ & $95 \mathrm{bc}$ & $1 \mathrm{a}$ & $4,150 \mathrm{~b}$ & $1 \mathrm{a}$ & $150 \mathrm{c}$ & $0 \mathrm{a}$ & $632 \mathrm{~d}$ & $1 \mathrm{a}$ & $365 \mathrm{de}$ & $37 \mathrm{a}$ & $2,828 \mathrm{bc}$ \\
\hline
\end{tabular}

${ }^{z}$ Plots were treated with Telone C-35 (65:35, 1,3-dichloropropene/chloropicrin; Dow Agrosciences, Indianapolis IN) at 433 kg/ha. Data were ln $(x+1)$ transformed prior to analysis; nontransformed means are presented. Values within and across F and NF columns within each year and nematode category followed by the same letter are not significantly different according to Tukey's adjustment for multiple comparisons $(P \geq 0.05 ; n=6$ subplots $)$. 
$P$. penetrans found in $R$. niveus roots grown in nonfumigated soil. During both years, there was no clear indication that any one particular raspberry cultivar or Rubus sp. was a better host for $P$. penetrans than another (Table 3).

Aboveground biomass of Cascade Bounty, Saanich, and Willamette was lower in nonfumigated versus fumigated soil 6 months after planting (Table 4). $R$. niveus produced the most aboveground biomass in fumigated soils, which was similar to the aboveground biomass of Meeker, Saanich, Willamette, and R. leucodermis. At the same sampling time, there were more differences detected belowground. Root biomass was less in Anne, Cascade Bounty, Meeker, Saanich, Willamette, and $R$. leucodermis in nonfumigated versus fumigated soils. In fumigated soil, $R$. leucodermis produced the largest root system while Heritage had the smallest root system. In 2012, 18 months after planting, there were no differences in above- and belowground biomass of plants grown in nonfumigated versus fumigated soil. Despite the lack of statistically significant differences, on average, above- and belowground biomass of plants grown in nonfumigated soils was approximately 50 and $30 \%$ less, respectively, than for plants grown in fumigated soil.
Root rot caused by Phytophthora rubi was never detected in the experimental area. $V$. dahliae was detected in soil or plants from $18 / 60$ nonfumigated subplots but only $3 / 60$ of the fumigated subplots. Soil populations of $V$. dahliae ranged from 1 to 13 propagules per $g$ of dry soil (ppg) in the infested subplots, with most populations averaging $1 \mathrm{ppg}$. By the end of the study, symptoms of Verticillium wilt were frequently observed on $R$. leucodermis in nonfumigated soil (approximately $50 \%$ of the plants) and less frequently on $R$. niveus (approximately $10 \%$ of the plants). Symptoms were rarely evident on these two species in fumigated soil and were almost never observed on raspberry cultivars regardless of fumigation treatment. $V$. dahliae was isolated from 20 plants in total: 16 plants from nonfumigated subplots and 4 plants from fumigated subplots. The most frequently infected genotypes were $R$. leucodermis ( 15 plants) and $R$. niveus (3 plants). Only two red raspberry cultivars (Cascade Bounty and Saanich) were found infected (one plant each), and both of these were located in nonfumigated subplots.

Influence of soil type on damage potential of Pratylenchus penetrans to red raspberry. Based upon initial Pratylenchus penetrans soil population densities in both trials, the pasteurized treatment

Table 2. Performance of raspberry (Rubus idaeus) cultivars, R. leucodermis, and R. niveus over a two-year period grown in soil fumigated (F) or not fumigated $(\mathrm{NF})^{\mathrm{v}}$

\begin{tabular}{|c|c|c|c|c|c|c|c|c|c|c|}
\hline \multirow[b]{3}{*}{ Cultivar or species } & \multicolumn{4}{|c|}{ Vigor $^{w}$} & \multirow{2}{*}{\multicolumn{2}{|c|}{$\begin{array}{c}\text { Height }(\mathrm{cm})^{\mathrm{x}} \\
2011\end{array}$}} & \multirow{2}{*}{\multicolumn{2}{|c|}{$\begin{array}{c}\begin{array}{c}\text { Shoot Biomass } \\
(\mathbf{k g})^{\mathrm{y}}\end{array} \\
2012\end{array}$}} & \multirow{2}{*}{\multicolumn{2}{|c|}{$\frac{\text { Yield }(\mathrm{g})^{\mathrm{z}}}{2012}$}} \\
\hline & \multicolumn{2}{|c|}{2011} & \multicolumn{2}{|c|}{2012} & & & & & & \\
\hline & $\mathbf{F}$ & NF & $\mathbf{F}$ & NF & $\mathbf{F}$ & NF & $\mathbf{F}$ & $\mathbf{N F}$ & $\mathbf{F}$ & $\mathbf{N F}$ \\
\hline Anne & $3.0 \mathrm{a}$ & $2.1 \mathrm{c}$ & $2.9 \mathrm{ab}$ & $2.1 \mathrm{~cd}$ & 87 bcde & 47 efghi & $4.5 \mathrm{~b}$ & $1.4 \mathrm{de}$ & 402 bcd & $55 \mathrm{hi}$ \\
\hline Caroline & $2.6 \mathrm{ab}$ & $2.0 \mathrm{~cd}$ & $2.6 \mathrm{abc}$ & $2.0 \mathrm{~d}$ & 66 defg & 26 ghi & $4.8 \mathrm{~b}$ & $1.4 \mathrm{de}$ & 259 cdefg & $0 \mathrm{i}$ \\
\hline Cascade Bounty & $2.5 \mathrm{abc}$ & $2.0 \mathrm{c}$ & $2.6 \mathrm{abcd}$ & $1.9 \mathrm{~d}$ & 57 defgh & $12 \mathrm{i}$ & $3.6 \mathrm{bc}$ & $0.3 \mathrm{f}$ & $746 \mathrm{ab}$ & $0 \mathrm{i}$ \\
\hline Chemainus & $2.2 \mathrm{bc}$ & $2.0 \mathrm{c}$ & $2.3 \mathrm{bcd}$ & $2.0 \mathrm{~d}$ & 49 efghi & $17 \mathrm{hi}$ & $4.0 \mathrm{~b}$ & $0.8 \mathrm{def}$ & 394 bcdef & $4 \mathrm{i}$ \\
\hline Heritage & $1.9 \mathrm{~cd}$ & $1.5 \mathrm{~d}$ & $1.9 \mathrm{de}$ & $1.6 \mathrm{e}$ & 23 ghi & $9 \mathrm{i}$ & $3.7 \mathrm{bc}$ & $0.3 \mathrm{ef}$ & 71 fghi & $8 \mathrm{hi}$ \\
\hline Meeker & $2.9 \mathrm{a}$ & $2.2 \mathrm{bc}$ & $3.0 \mathrm{a}$ & $2.2 \mathrm{~cd}$ & $112 b c$ & 70 cdef & $4.9 \mathrm{~b}$ & $1.1 \mathrm{def}$ & $1056 \mathrm{a}$ & 191 defgh \\
\hline Saanich & $2.8 \mathrm{a}$ & $2.1 \mathrm{c}$ & $2.8 \mathrm{ab}$ & $2.0 \mathrm{~d}$ & 80 cdef & 41 fghi & $5.6 \mathrm{~b}$ & $2.0 \mathrm{~cd}$ & 352 bcde & $42 \mathrm{hi}$ \\
\hline Willamette & $2.9 \mathrm{a}$ & $2.1 \mathrm{c}$ & $2.9 \mathrm{ab}$ & $2.2 \mathrm{~cd}$ & $98 \mathrm{bcd}$ & 58 defgh & $4.5 \mathrm{~b}$ & $0.9 \mathrm{def}$ & $564 \mathrm{abc}$ & 71 ghi \\
\hline R. leucodermis & $2.9 \mathrm{a}$ & $2.4 \mathrm{abc}$ & $2.9 \mathrm{ab}$ & $2.4 \mathrm{abcd}$ & $176 \mathrm{a}$ & $124 \mathrm{~b}$ & $4.8 \mathrm{~b}$ & $1.3 \mathrm{de}$ & $433 \mathrm{bcd}$ & 95 efghi \\
\hline$R$. niveus & $3.0 \mathrm{a}$ & $2.5 \mathrm{abc}$ & $2.9 \mathrm{ab}$ & $2.6 \mathrm{abcd}$ & $96 \mathrm{bcd}$ & 82 bcdef & $9.5 \mathrm{a}$ & $6.2 \mathrm{ab}$ & na & na \\
\hline
\end{tabular}

v Plots were treated with Telone C-35 (65:35, 1,3-dichloropropene/chloropicrin; Dow Agrosciences, Indianapolis IN) at $433 \mathrm{~kg} / \mathrm{ha}$. Plant biomass and yield data were square root transformed prior to analysis; nontransformed means are presented. Values within and across $\mathrm{F}$ and $\mathrm{NF}$ columns within each year and plant parameter followed by the same letter are not significantly different according to Tukey's adjustment for multiple comparisons $(P \geq 0.05 ; n=6$ subplots); na $=$ not available.

${ }^{w}$ Vigor was assessed on a 0 -to-3 scale with 0 being dead and 3 being healthy; three to five vigor assessments were taken per subplot and averaged to obtain a single value for each subplot.

${ }^{x}$ Height of five plants per subplot (five total) was measured and used to calculate the average height per subplot.

${ }^{y}$ Shoot biomass was assessed by mowing the canes remaining in each subplot at the end of the experiment in September 2012 and drying to determine aboveground dry biomass weight per subplot.

${ }^{\text {z }}$ Plots were machine harvested four times between 21 July and 8 August 2012; values represent the sum of these harvests in each subplot.

Table 3. Population densities of Pratylenchus penetrans in roots of destructively harvested raspberry (Rubus idaeus) cultivars, $R$. leucodermis, and $R$. niveus grown in soil that was either fumigated $(\mathrm{F})$ or not fumigated $(\mathrm{NF})$

\section{P. penetrans nematodes ${ }^{\mathrm{Z}}$}

\begin{tabular}{|c|c|c|c|c|c|c|c|c|}
\hline \multirow[b]{3}{*}{ Cultivar or species } & \multicolumn{4}{|c|}{ Fall 2011} & \multicolumn{4}{|c|}{ Fall 2012} \\
\hline & \multicolumn{2}{|c|}{ Per g of root } & \multicolumn{2}{|c|}{ Total in roots } & \multicolumn{2}{|c|}{ Per g of root } & \multicolumn{2}{|c|}{ Total in roots } \\
\hline & $\mathbf{F}$ & NF & $\mathbf{F}$ & NF & $\mathbf{F}$ & NF & $\mathbf{F}$ & NF \\
\hline Anne & $28 \mathrm{ab}$ & $5,218 d$ & $576 \mathrm{ab}$ & $40,371 \mathrm{e}$ & 146 abcde & 2,346 ef & $42,598 \mathrm{abc}$ & $552,523 \mathrm{bc}$ \\
\hline Caroline & $34 a b$ & $3,768 d$ & $264 \mathrm{ab}$ & $15,507 \mathrm{e}$ & 198 bcdef & 2,164 cdef & $37,926 \mathrm{bc}$ & $351,425 \mathrm{bc}$ \\
\hline Cascade Bounty & $5 \mathrm{ab}$ & $3,930 \mathrm{~d}$ & $69 \mathrm{ab}$ & $15,078 \mathrm{e}$ & $82 \mathrm{abc}$ & 2,679 ef & $32,580 \mathrm{abc}$ & $462,812 \mathrm{bc}$ \\
\hline Chemainus & $200 \mathrm{bc}$ & $3,590 \mathrm{~d}$ & $1,351 \mathrm{bcd}$ & 16,242 cde & 317 bcdef & $4,094 \mathrm{f}$ & $100,545 \mathrm{bc}$ & $699,925 \mathrm{c}$ \\
\hline Heritage & $41 \mathrm{ab}$ & $3,331 \mathrm{~d}$ & $363 a b$ & $14,200 \mathrm{de}$ & 369 bcdef & $4,688 \mathrm{f}$ & $50,477 \mathrm{abc}$ & $481,623 \mathrm{bc}$ \\
\hline Meeker & $33 \mathrm{ab}$ & $1,078 \mathrm{~d}$ & $533 \mathrm{bc}$ & 7,031 cde & 244 bcdef & $2,969 \mathrm{f}$ & $77,253 \mathrm{bc}$ & $564,705 \mathrm{bc}$ \\
\hline Saanich & $2 \mathrm{a}$ & $3,023 \mathrm{~d}$ & $26 \mathrm{a}$ & 11,853 cde & 247 abcd & 2,486 def & $88,554 \mathrm{abc}$ & $539,782 \mathrm{bc}$ \\
\hline Willamette & $33 a b$ & $2,577 \mathrm{~d}$ & $769 \mathrm{ab}$ & $22,827 \mathrm{e}$ & $109 \mathrm{abc}$ & $1,631 \mathrm{def}$ & $46,248 \mathrm{abc}$ & $217,157 \mathrm{bc}$ \\
\hline R. leucodermis & $138 \mathrm{ab}$ & $1,008 \mathrm{~d}$ & $3,103 \mathrm{ab}$ & $11,855 \mathrm{e}$ & $45 \mathrm{ab}$ & $1,565 \mathrm{def}$ & $9,153 \mathrm{ab}$ & $333,035 \mathrm{bc}$ \\
\hline$R$. niveus & $2 \mathrm{a}$ & $765 \mathrm{~cd}$ & $32 \mathrm{ab}$ & 11,853 cde & $4 \mathrm{a}$ & 2,070 cdef & $2,168 \mathrm{a}$ & $870,088 \mathrm{bc}$ \\
\hline
\end{tabular}

${ }^{z}$ Plots were treated with Telone C-35 (65:35, 1,3-dichloropropene/chloropicrin; Dow Agrosciences, Indianapolis IN) at $433 \mathrm{~kg} / \mathrm{ha}$. Data were $1 \mathrm{n}(x+1)$ transformed prior to analysis; nontransformed means are presented. Values within and across F and NF columns within each year and nematode category followed by the same letter are not significantly different according to Tukey's adjustment for multiple comparisons $(P \geq 0.05 ; n=6$ subplots) 
eliminated $P$. penetrans from both soil types successfully (Table 5). In both trials, the nematicide treatment did not eliminate $P$. penetrans from either of the soil types, resulting in population densities of $P$. penetrans similar to the low or high treatments or both. Across soil types and treatments, significantly greater $P$. penetrans population densities were established in the high treatment than the low treatments, except in trial 2 sandy loam soil, where populations were similar in these two treatments. By the end of the trials, $P$. penetrans was still undetectable in the pasteurized treatment in both soils (Table 5). In the sandy loam soil in both trials, regardless of the initial population density of $P$. penetrans, root and soil $P$. penetrans densities were similar at the end of the experiments (Table 5). Results were more variable in the silt loam soil. In trial 1 , there were more than twice the number of $P$. penetrans nematodes in soil in the high treatment than in the corresponding nematicide and low treatments. In trial 2, there were 4.3 and 2.6 times more nematodes in soil and roots, respectively, of the high treatment than in the nematicide and low treatments in the silt loam.

At the end of the experiment (6 months after planting), within trials, raspberry plants grew similarly in the different soil types when pasteurized (Table 5). In both trials 1 and 2 in the sandy loam soil, total plant biomass was $46 \%$ lower in all treatments that contained $P$. penetrans compared with the corresponding pasteurized treatment. However, in the silt loam soil, total plant biomass was 47 and 54\% lower only in trial 1 in the nematicide and high treatments, respectively, compared with the pasteurized treatment. In general, shoot dry weights followed the same pattern among treatments as total plant biomass (data not shown). Likewise, trial 1 root biomass followed a similar pattern to that of total plant biomass, with approximately $50 \%$ less root biomass in both the nematicide and high treatments in both soils compared with the corresponding pasteurized treatment. In trial 2, there were few differences in root biomass across the soil types and treatments; only plants grown in the nematicide treatment in the sandy loam soil had 50\% less root biomass than corresponding plants in the pasteurized treatment (data not shown). The height and number of primocanes were not affected by soil type or soil treatment in either trial (data not shown).

\section{Discussion}

All of the raspberry cultivars included in this study were excellent hosts for $P$. penetrans, indicating that cultivar selection is not a viable means by which to manage the damage caused by this nematode to raspberry. Establishment and productivity of all the raspberry cultivars were diminished in the presence of $P$. penetrans. At the end of the study, 18 months after planting, aboveground biomass and yields were less in all cultivars grown in nonfumigated fine sandy loam soil compared with fumigated soil. Averaged across cultivars, the losses in biomass and yield were 77 and 92\%, respectively. Meeker was similarly affected in the microplot experiment, exhibiting $46 \%$ less plant biomass when inoculated with $P$. penetrans in the sandy loam soil.

Similar losses in biomass and yield have been reported previously in other red raspberry cultivars affected by $P$. penetrans. In a 2-year study of Willamette, there was $24 \%$ plant mortality and pruning weights were $66 \%$ lower in plots with $P$. penetrans compared with plants grown without $P$. penetrans within 6 months after planting and inoculation (17). At the end of the study, 18 months after planting, there were $410 P$. penetrans nematodes per $100 \mathrm{~cm}^{3}$ of soil, and raspberry yield of plants infected with $P$. penetrans was $47 \%$ lower than in plants without $P$. penetrans. At the same time, cane numbers were also $31 \%$ lower in plants with $P$. penetrans compared with those without but there was no impact of $P$. penetrans on cane length and fruit weight. In another experiment, the effect of preplant fumigation on the productivity of Boyne and respective population dynamics of plant-parasitic nematodes was examined over a 5-year period (2). Two years after planting, the number and length of canes were 54 and $36 \%$ less, respectively, in nonfumigated compared with fumigated plots. Total yield of plants grown in nonfumigated plots was also lower $(52 \%)$ than that of plants in corresponding fumigated plots. Cane number and yield continued to be lower in nonfumigated plots compared with fumigated plots 3 and 4 years after planting. In the final year of this study (2), there were no differences in any the measured plant parameters between plants in nonfumigated and fumigated plots. Although other plant-parasitic nematodes were found in this study, including $X$. rivesi and $M$. hapla, $P$. penetrans was the most abundant nematode present at the end of the experiment (233 nematodes per $100 \mathrm{~cm}^{3}$ ) and, therefore, was presumed to have caused most of the reduction in growth of raspberry. In our study, we did not observe mortality of raspberry cultivars but vigor, cane biomass, and yield were 22,77 , and $92 \%$ lower, respectively, in nonfumigated soil compared with fumigated soil 18 months after initial exposure to $P$. penetrans. Our data set clearly demonstrates that, in addition to Boyne and Willamette raspberry, Anne, Caroline, Cascade Bounty, Chemainus, Heritage, Meeker, and Saanich are all very susceptible to damage caused by $P$. penetrans.

$R$. leucodermis and $R$. niveus, both identified as poor hosts for $P$. penetrans in greenhouse studies (39), were excellent hosts for $P$. penetrans in the field. The reason for this discrepancy is unclear; however, the finding that $R$. leucodermis and $R$. niveus are excellent hosts for $P$. penetrans in a field setting indicates that neither of these species should be used as a source of resistance to $P$. penetrans in breeding programs. Despite being an excellent host for $P$. penetrans, $R$. niveus appeared to be tolerant of the nematode. By the end of the study, there was a similar amount of $R$. niveus biomass collected from

Table 4. Root and shoot biomass of destructively harvested raspberry (Rubus idaeus) cultivars, $R$. leucodermis, and $R$. niveus grown in soil that was either fumigated $(\mathrm{F})$ or not fumigated $(\mathrm{NF})^{\mathrm{z}}$

2011

\begin{tabular}{|c|c|c|c|c|c|c|c|c|}
\hline \multirow[b]{3}{*}{ Cultivar/species } & & \\
\hline & \multicolumn{2}{|c|}{ Shoot biomass (g) } & \multicolumn{2}{|c|}{ Root biomass (g) } & \multicolumn{2}{|c|}{ Shoot biomass (g) } & \multicolumn{2}{|c|}{ Root biomass (g) } \\
\hline & $\mathbf{F}$ & NF & $\mathbf{F}$ & NF & $\mathbf{F}$ & NF & $\mathbf{F}$ & NF \\
\hline Anne & 76.7 cde & $28.4 \mathrm{efg}$ & $28.6 \mathrm{abc}$ & $9.3 \mathrm{fgh}$ & $1,620.0 \mathrm{abc}$ & $455.0 \mathrm{~cd}$ & $378.3 \mathrm{ab}$ & $212.5 \mathrm{ab}$ \\
\hline Caroline & $53.0 \mathrm{defg}$ & $16.9 \mathrm{fg}$ & 11.0 defgh & $4.3 \mathrm{~h}$ & $2,446.7 \mathrm{ab}$ & $1,235.8 \mathrm{abcd}$ & $244.2 \mathrm{ab}$ & $278.3 \mathrm{ab}$ \\
\hline Cascade Bounty & 85.8 bcde & $6.2 \mathrm{~g}$ & $15.3 \mathrm{cdef}$ & $4.0 \mathrm{~h}$ & $2,023.3 \mathrm{abc}$ & $918.3 \mathrm{bcd}$ & $325.0 \mathrm{ab}$ & $233.3 \mathrm{ab}$ \\
\hline Chemainus & $58.4 \mathrm{def}$ & $8.3 \mathrm{fg}$ & 10.0 efgh & $4.1 \mathrm{~h}$ & $1,690.0 \mathrm{abc}$ & $500.8 \mathrm{bcd}$ & $371.7 \mathrm{ab}$ & $184.2 \mathrm{ab}$ \\
\hline Heritage & $18.9 \mathrm{fg}$ & $5.3 \mathrm{~g}$ & $6.4 \mathrm{gh}$ & $4.8 \mathrm{~h}$ & 1,169.2 abcd & $78.3 \mathrm{~d}$ & $178.3 \mathrm{ab}$ & $118.3 \mathrm{~b}$ \\
\hline Meeker & $124.4 \mathrm{abcd}$ & $47.6 \mathrm{defg}$ & 19.1 bcdef & $6.3 \mathrm{~h}$ & $1,805.0 \mathrm{abc}$ & $1,023.3 \mathrm{bcd}$ & $305.8 \mathrm{ab}$ & $194.2 \mathrm{ab}$ \\
\hline Saanich & $120.8 \mathrm{abcd}$ & 49.9 efg & $21.4 \mathrm{bcd}$ & $4.5 \mathrm{~h}$ & $2,208.3 \mathrm{ab}$ & $703.3 \mathrm{bcd}$ & $413.3 \mathrm{a}$ & $243.3 \mathrm{ab}$ \\
\hline Willamette & $210.0 \mathrm{a}$ & $34.6 \mathrm{efg}$ & $31.1 \mathrm{ab}$ & 9.0 efgh & 1,403.3 abcd & $1,007.5 \mathrm{bcd}$ & $392.5 \mathrm{ab}$ & $175.0 \mathrm{ab}$ \\
\hline R. leucodermis & $174.0 \mathrm{abc}$ & $126.7 \mathrm{abcd}$ & $42.0 \mathrm{a}$ & 18.8 bcde & $1,268.3 \mathrm{abc}$ & $959.2 \mathrm{bcd}$ & $270.8 \mathrm{ab}$ & $260.8 \mathrm{ab}$ \\
\hline$R$. niveus & $240.0 \mathrm{a}$ & $193.3 \mathrm{ab}$ & $20.3 \mathrm{bcd}$ & $15.0 \mathrm{defg}$ & $3,207.5 \mathrm{a}$ & $1,839.2 \mathrm{abc}$ & $369.0 \mathrm{ab}$ & $374.2 \mathrm{ab}$ \\
\hline
\end{tabular}


nonfumigated soil versus fumigated soil; this was the only cultivar or species for which this was observed. This tolerance may have been the result of $R$. niveus being able to maintain a relatively large, functional root system even in the presence of high $P$. penetrans population densities. The potential of $R$. leucodermis was likely not realized in this study because of the additional susceptibility to $V$. dahliae.

Soil fumigation with 1,3-dichloropropene and chloropicrin is an important component of soilborne disease and nematode management in raspberry production systems. In northern Washington, $95 \%$ of replanted and $50 \%$ of newly planted fields are fumigated prior to the establishment of raspberry (20). It is known that soil fumigation does not eliminate all nematodes from soil and that populations will increase gradually on a susceptible host after planting (22). In the raspberry fumigation trial by Bélair (2), soil fumigation with 1,3-dichloropropene kept population densities of $P$. penetrans below levels observed in the nontreated control for 3 years after fumigation. In our field trial, the apparent length of time that $P$. penetrans population densities remained lower in fumigated soil than nonfumigated soil was dependent on the sampling methods. When composite samples based on multiple plants/subplot were used, the effect of fumigation on $P$. penetrans population densities was still evident at the end of the study ( 2 years after fumigation). However, when destructive samples based on a single plant/subplot were used, the effect of fumigation was often not significant. In both methods, population densities of $P$. penetrans nematodes per gram of root ranged from 7 to 518 times greater in nonfumigated soil than in fumigated soil. However, in the latter case, we found that the sample size in our destructive sampling method was not large enough to encompass the large amount of variability in $P$. penetrans population densities between individual plants collected from each cultivar or Rubus sp. subplot. For example, variances in 2012 P. penetrans population densities ( $P$. penetrans nematodes per gram of root) from the September 2012 destructive harvest and based on a single plant/ subplot were approximately five times larger than the composite samples from the same time period based on multiple plants per subplot. This lower variability from the composite sampling method allowed for differences in treatments to be observed.

Although the results from the two microplot trials were not consistent, they suggested that fewer $P$. penetrans nematodes in a sandy loam soil were needed to cause damage comparable with that caused by larger numbers in a silt loam soil. This conclusion is supported by previous research which showed that larger particles and pore size in sandy soils versus silty or loamy soil types were more suitable for movement and penetration of the plant hosts by $P$. penetrans $(9,29)$. Coarse-textured soils, such as sandy loam soils, also favor raspberry growth (6). In this study, there was no significant difference in plant growth between the pasteurized sandy loam and silt loam soils, which may reflect the fact that the volume of the buckets limited the growth of raspberry roots compared with plants grown in field plots where roots are not constricted. The lack of significant differences in plant growth between the infested sandy loam and silt loam soils may also be the result of a combination of factors (e.g., the sandy loam soil was more beneficial to the growth of raspberry plants but also more suitable for $P$. penetrans than the silt loam soil). A longer period of growth or greater $P$. penetrans population densities may induce even more severe damage in the sandy loam soil than in the silt loam soil, although this was not evaluated in this study.

Based on the literature and our observations, most of the damage that was observed in this study can be attributed to $P$. penetrans. However, it is suspected that raspberry suffers from a replant issue similar to that reported in other perennial crops (16), although there has been comparatively little research to formally describe raspberry replant disease or its causative agents $(24,38)$. The only other soilborne pathogen that has received extensive attention in raspberry is Phytophthora rubi (37). Although it has been reported that this pathogen can cause extensive damage to raspberry $(8,36)$, it is unlikely that $P$. rubi contributed to the damage observed in our trial because we applied fungicides, and typical symptoms of root rot were not observed. We did find $V$. dahlia sporadically across the trial location but actual symptoms of Verticillium wilt were primarily limited to $R$. leucodermis and $R$. niveus, from which the pathogen was isolated most frequently. Although damage by $V$. dahliae (reported as Acrostalagmus caulophagus and $V$. albo-atrum) has been reported on raspberry in the region for over 100 years $(14,40)$, typical wilt symptoms were not observed on this host and the pathogen was only isolated twice from raspberry cultivars in the present study. Previous research has suggested that red raspberry is less susceptible to $V$. dahliae (reported as $V$. albo-atrum) than black raspberry species $(10,40)$, which may explain why $R$. leucodermis and $R$. niveus were the most commonly infected plants in this study. Other soilborne pathogens that have been isolated from unhealthy raspberry plants include Rhizoctonia, Fusarium, Cylindrocarpon, and Pythium spp. $(24,38)$. Of these, $R$. fragariae caused varying degrees of foliar chlorosis and root lesions (38) but the presence or absence of these soilborne pathogens was not evaluated in this study.

All of the most commonly planted raspberry cultivars (35) grown in the Pacific Northwest region of North America are extremely susceptible to damage caused by Pratylenchus penetrans. The results suggest that management practices other than plant selection will be necessary to keep population densities of this nematode in check. It appears that site selection might be an important factor in minimizing

Table 5. Pratylenchus penetrans population densities and biomass of raspberry (Rubus idaeus) Meeker as affected by soil type and soil treatment in a microplot study ${ }^{x}$

\begin{tabular}{|c|c|c|c|c|}
\hline \multirow{3}{*}{$\begin{array}{l}\text { Trial, soil type, } \\
\text { treatment }^{y}\end{array}$} & \multicolumn{3}{|c|}{ P. penetrans nematodes } & \multirow{3}{*}{$\begin{array}{l}\text { Total plant } \\
\text { biomass }(g)\end{array}$} \\
\hline & \multicolumn{2}{|c|}{ Per $100 \mathrm{~g}$ of soil } & \multirow{2}{*}{$\begin{array}{c}\begin{array}{c}\text { Per g of } \\
\text { dry root }\end{array} \\
\text { Final }\end{array}$} & \\
\hline & Initial & Final & & \\
\hline \multicolumn{5}{|l|}{ Trial 1} \\
\hline \multicolumn{5}{|l|}{ Sandy loam } \\
\hline Pasteurized $^{\mathrm{z}}$ & 0 & 0 & 0 & $192 \mathrm{a}$ \\
\hline Nematicide & $6 \mathrm{c}$ & $23 \mathrm{~b}$ & $113 \mathrm{bcd}$ & $110 \mathrm{c}$ \\
\hline Low & $11 \mathrm{c}$ & $11 \mathrm{~b}$ & $36 \mathrm{~d}$ & $112 \mathrm{c}$ \\
\hline High & $50 \mathrm{ab}$ & $39 \mathrm{~b}$ & $69 \mathrm{~cd}$ & $91 \mathrm{c}$ \\
\hline \multicolumn{5}{|l|}{ Silt loam } \\
\hline Pasteurized $^{\mathrm{z}}$ & 0 & 0 & 0 & $179 \mathrm{ab}$ \\
\hline Nematicide & $18 \mathrm{bc}$ & $31 \mathrm{~b}$ & $244 \mathrm{abc}$ & $95 \mathrm{c}$ \\
\hline Low & $51 \mathrm{~b}$ & $46 \mathrm{~b}$ & $335 \mathrm{ab}$ & $124 \mathrm{bc}$ \\
\hline High & $126 \mathrm{a}$ & $100 \mathrm{a}$ & $448 \mathrm{a}$ & $83 \mathrm{c}$ \\
\hline \multicolumn{5}{|l|}{ Trial 2} \\
\hline \multicolumn{5}{|l|}{ Sandy loam } \\
\hline Pasteurized & 0 & 0 & 0 & $212 \mathrm{a}$ \\
\hline Nematicide & $41 \mathrm{~b}$ & $51 \mathrm{ab}$ & $71 \mathrm{c}$ & $123 \mathrm{bc}$ \\
\hline Low & $12 \mathrm{~b}$ & $52 \mathrm{a}$ & $162 \mathrm{~b}$ & $111 \mathrm{bc}$ \\
\hline High & $12 \mathrm{~b}$ & $40 \mathrm{ab}$ & $142 \mathrm{bc}$ & $113 \mathrm{bc}$ \\
\hline \multicolumn{5}{|l|}{ Silt loam } \\
\hline Pasteurized & 0 & 0 & 0 & $150 \mathrm{abc}$ \\
\hline Nematicide & $15 \mathrm{~b}$ & $9 \mathrm{~b}$ & $187 \mathrm{~b}$ & $169 \mathrm{ab}$ \\
\hline Low & $18 \mathrm{~b}$ & $41 \mathrm{ab}$ & $225 \mathrm{~b}$ & $101 \mathrm{c}$ \\
\hline High & $72 \mathrm{a}$ & $63 \mathrm{a}$ & $538 \mathrm{~b}$ & $143 \mathrm{bc}$ \\
\hline
\end{tabular}

${ }^{\mathrm{x}}$ To fit the assumptions of equal variance or normality, all $P$. penetrans population densities data were square root transformed for trial 1 . For trial 2, initial $P$. penetrans population density data were arcsine transformed, and final $P$. penetrans population density data in roots were square root transformed. For both trials, root dry weight data were square root transformed. For all data, nontransformed means are presented. Values followed by the same letter are not significantly different according to Student's $t$ test $(P \geq$ $0.05 ; n=5$ ).

${ }^{y}$ Pasteurized treatment was established by heating soil to $60^{\circ} \mathrm{C}$ with steam for $1 \mathrm{~h}$. The nematicide treatment was established by treating soil with a combination of the nematicides oxamyl (oxamyl at $367 \mathrm{~g} / \mathrm{ha}$ and Vydate $\mathrm{L}$ at $0.22 \mathrm{ml} /$ liter of soil) and fosthiazate (fosthiazate at $5,044 \mathrm{~g} / \mathrm{ha}$ and fosthiazate EC900 at $0.13 \mathrm{ml} /$ liter of soil). The low and high treatments were established by mixing nematicide-treated soil with nontreated soil to achieve target populations.

${ }^{\mathrm{z}}$ To avoid extremely heterogeneous variances, $P$. penetrans population densities in the pasteurized soil treatment were not included in the data analysis with other treatments. 
the impact of $P$. penetrans on raspberry productivity, with our results indicating that the damage potential of $P$. penetrans is greater on sandy loam versus silt loam soils; however, understanding what makes a field conducive for $P$. penetrans to cause damage needs to be further explored. Despite the fact that fumigation is becoming increasingly limited by regulations, this study shows the utility of fumigation in reducing $P$. penetrans populations for a sufficient period of time to ensure that newly planted raspberry fields can become established.

\section{Acknowledgments}

We thank J. Pinkerton, D. Kroese, A. Davis, B. Beck, and D. Wallace for technical assistance. This research was partially funded by the United States Department of Agriculture NIFA-RAMP grant 2010-51101-21649.

\section{Literature Cited}

1. Ayoub, S. M. 1980. Plant Nematology, An Agricultural Training Aid. NemaAid Publications, Sacramento, CA.

2. Bélair, G. 1991. Effects of preplant soil fumigation on nematode population densities and on growth and yield of raspberry. Phytoprotection 72:21-25.

3. Berkeley, G. H., and Jackson, A. B. 1926. Verticillium wilt of the red raspberry. Sci. Agric. 6:261-270.

4. Butterfield, E. J., and DeVay, J. E. 1977. Reassessment of soil assays for Verticillium dahliae. Phytopathology 67:1073-1078.

5. Castillo, P., and Vovlas, N. 2007. Page 529 in: Pratylenchus (Nematoda: Pratylenchidae). Diagnosis, Biology, Pathogenicity and Management. Nematology Monographs \& Perspectives, Leiden, The Netherlands.

6. Crandall, P. C., and Daubeny, H. A. 1990. Raspberry management. Pages 157-212 in: Small Fruit Crop Management. G. J. Galletta and D. G. Himelrick, eds. Prentice Hall, Englewood Cliffs, NJ.

7. Davis, E. L., and MacGuidwin, A. E. 2005. Lesion nematode disease. Plant Health Instructor. Online publication. .

8. Duncan, J. M., Kenedy, D. M., and Scott, P. H. 1991. Relationships between non-papillate soilborne species of Phytophthora: Root rot of raspberry. Pages 129-147 in: Phytophthora. J. A. Lucas, R. C. Shattock, D. S. Shaw, and L. R. Cooke, eds. Cambridge University Press, Cambridge, UK.

9. Endo, B. Y. 1959. Responses of root-lesion nematodes, Pratylenchus brachyurus and $P$. zeae, to various plants and soil types. Phytopathology 49: 417-421.

10. Fiola, J. A., and Swartz, H. J. 1994. Inheritance and tolerance to Verticillium albo-atrum in raspberry. HortScience 29:1071-1073.

11. Forge, T. A., DeYoung, R., and Vrain, T. C. 1998. Temporal changes in the vertical distribution of Pratylenchus penetrans under raspberry. J. Nematol. 30:179-183.

12. Gigot, J., Walters, T. W., and Zasada, I. A. 2013. Impact and occurrence of Phytophthora rubi and Pratylenchus penetrans in commercial red raspberry (Rubus idaeus) fields in northwestern Washington. Int. J. Fruit Sci. 13: 357-372.

13. Hawksworth, D. L., and Talboys, P. W. 1970. Verticillium dahliae. In: CMI Descriptions of Pathogenic Fungi and Bacteria. No. 256. CAB International, Wallingford, UK

14. Lawrence, W. H. 1912. Bluestem of the black raspberry. Agric. Exp. Station Bull. 108. State College of Washington, Pullman, WA

15. Lower Mainland Horticulture Improvement Association. 2005. Berry Production Guide. Lower Mainland Horticulture Improvement Association, Vancouver, British Columbia, Canada.

16. Mazzola, M., and Manici, L. M. 2012. Apple replant disease: Role of microbial ecology in cause and control. Annu. Rev. Phytopathol. 50:45-65.

17. McElroy, F. D. 1977. Distribution of stylet-bearing nematodes associated with raspberries and strawberries in British Columbia. Can. Plant Dis. Surv. 57:3-8.

18. McElroy, F. D. 1977. Effect of two nematode species on establishment, growth, and yield of raspberry. Plant Dis. Rep. 61:277-279.
19. McElroy, F. D. 1992. A plant health care program for brambles in the Pacific Northwest. J. Nematol. 24:457-462.

20. Menzies, G. W. 1999. Crop Profile for Raspberries (Red) in Washington. Washington State University Cooperative Extension, Pullman.

21. Norton, D. C. 1979. Relationship of physical and chemical factors to populations of plant-parasitic nematodes. Annu. Rev. Phytopathol. 17: 279-299.

22. Perry, V. G. 1953. Return of nematodes following fumigation of Florida soils. Proc. Fla. State Hortic. Soc. 66:112-114.

23. Saxton, A. M.1998. A macro for converting mean separation output to letter groupings in Proc Mixed. Pages 1243-1246 in: Proc. 23rd SAS Users Group Int. SAS Institute, Cary, NC.

24. Schilder, A. C.2007. Determining the role of Rhizoctonia, Pythium, and Cylindrocarpon in replant disorder of raspberry. In: North Am. Bramble Growers Assoc. 2007 Conf. Proc. 25-34.

25. Schmitt, D. P., and Barker, K. R. 1981. Damage and reproductive potentials of Pratylenchus brachyurus and $P$. penetrans on soybean. J. Nematol. 13: 327-332.

26. Shah, D. A., and Madden, L. V. 2004. Nonparametric analysis of ordinal data in designed factorial experiments. Phytopathology 94:33-43.

27. Sorensen, L. H., Schneider, A. T., and Davis, J. R. 1991. Influence of sodium polygalacturonate sources and improved recovery of Verticillium spp. from soil. (Abstr.) Phytopathology 81:1347.

28. Townshend, J. L. 1972. Influence of edaphic factors on penetration of corn roots by Pratylenchus penetrans and $P$. minyus in three Ontario soils. Nematologica 18:201-212.

29. Townshend, J. L., and Webber, L. R. 1971. Movement of Pratylenchus penetrans and the moisture characteristics of three Ontario soils. Nematologica 17:47-57.

30. United States Department of Agriculture. 2014. Noncitrus fruits and nuts 2013 summary. http://usda.mannlib.cornell.edu/usda/nass/NoncFruiNu/2010s/ 2014/NoncFruiNu-07-17-2014_revision.txt

31. United States Environmental Protection Agency. 2008. Fenamiphos facts. Online publication. http://www.epa.gov/pesticides/reregistration/REDs/factsheets/ fenamiphos ired fs.htm

32. United States Environmental Protection Agency. 2012. Soil fumigant mitigation factsheet: Phase 2 site-specific fumigant management plans and post-application summaries. Office of Pesticide Programs (7506P), EPA 735F-12-007.

33. Vrain, T. C., Forge, T. A., and DeYoung, R. 1997. Population dynamics of Pratylenchus penetrans parasitizing raspberry. Fundam. Appl. Nematol. 20: 29-36.

34. Walters, T. W., Pinkerton, J. N., Riga, E., Zasada, I. A., Partika, M., Yoshida, H. A., and Ishida, C. 2009. Managing plant-parasitic nematodes in established red raspberry fields. Horttechnology 19:762-768.

35. Washington Red Raspberry Commission. 2010. U.S. Red Raspberry Council. Online publication. http://www.red-raspberry.org/worldNews.asp

36. Wilcox, W. F. 1989. Virulence and isolation frequency of seven Phytophthora spp. causing root rot of raspberry in New York. Phytopathology 79: 93-101.

37. Wilcox, W. F. 1991. Phytophthora root rot. Pages 34-36 in: Compendium of Raspberry and Blackberry Diseases and Insects. M. A. Ellis, R. H. Converse, R. N. Williams, and B. Williamson, eds. American Phytopathological Society, St. Paul, MN.

38. You, R., Sweeney, M., Kempler, C., and Sabaratnam, S. 2006. Investigation of root rot complex on raspberries grown in the lower Fraser valley of British Columbia. Can. J. Plant Pathol. 28:370 (abstr.)

39. Zasada, I. A., and Moore, P. P. 2014. Host status of Rubus species and hybrids for the root lesion nematode, Pratylenchus penetrans. HortScience 49: 1128-1131.

40. Zeller, S. M. 1936. Verticillium Wilt of Cane Fruits. Agricultural Experiment Station, Oregon State Agricultural College, Corvallis. 